NBER WORKING PAPER SERIES

\title{
WILLINGNESS TO PAY FOR DRUG REHABILITATION: IMPLICATIONS FOR COST RECOVERY
}

\author{
David Bishai \\ Jody Sindelar \\ Working Paper 12506 \\ http://www.nber.org/papers/w12506
NATIONAL BUREAU OF ECONOMIC RESEARCH
1050 Massachusetts Avenue
Cambridge, MA 02138
September 2006

Funding for this research was provided by grant number R01- DA09225 funded by the National Institute on Drug Abuse. In addition, the authors would like to thank study participants and staff of the Baltimore Needle Exchange Project. The authors gratefully acknowledge research support for JS from the National Institute on Drug Abuse to Yale (Grant No. R01-DA14471). The views expressed herein are those of the author(s) and do not necessarily reflect the views of the National Bureau of Economic Research.

(C2006 by David Bishai and Jody Sindelar. All rights reserved. Short sections of text, not to exceed two paragraphs, may be quoted without explicit permission provided that full credit, including $\odot$ notice, is given to the source. 
Willingness to Pay for Drug Rehabilitation: Implications for Cost Recovery

David Bishai and Jody Sindelar

NBER Working Paper No. 12506

September 2006

JEL No. I1, I10

\begin{abstract}
Objectives: This study estimates the value that clients place on drug rehabilitation services at the time of intake and how this value varies with the probability of success and availability of social services.

Methods: We interviewed 241 heroin users who had been referred to, but had not yet entered, methadone maintenance treatment in Baltimore, Maryland. We asked each subject to state a preference among three hypothetical treatment programs that varied across 3 domains: weekly fee paid by the client out of pocket ( $\$ 5$ to $\$ 100$ ), presence/absence of case management, and time spent heroin-free (3 to 24 months). Each subject was asked to complete 18 orthogonal comparisons. Subsequently each subject was asked if they likely would enroll in their preferred choice among the set of three. We computed the expected willingness to pay (WTP) as the probability of enrollment times the fee considered in each choice considered from a multivariate logistic model that controlled for product attributes. We also estimated the price elasticity of demand.
\end{abstract}

Results: We found that $21 \%$ of clients preferred programs that were logically dominated by other options. The median expected fee subjects were willing to pay for a program that offered 3 months of heroin-free time was $\$ 7.30$ per week, rising to $\$ 17.11$ per week for programs that offered 24 months of heroin-free time. The availability of case management increased median WTP by \$5.64 per week. The fee was the most important predictor of the self-reported probability of enrollment with a price elasticity of -0.39 (SE 0.042).

Conclusions: Clients' median willingness to pay for drug rehabilitation fell short of the average program costs of $\$ 82$ per week, which reinforces the need for continued subsidization as drug treatment has high positive externalities. Clients will pay more for higher rates of treatment success and for the presence of case management.

Jody Sindelar

Yale School of Public Health

Yale University School of Medicine

60 College Street, P.O. Box 208034

New Haven, CT 06520-8034

and NBER

jody.sindelar@yale.edu 


\section{Introduction}

The economic burden of illicit drug use was estimated at \$143 billion in 1998 (\$160 billion in 2003) (Cartwright, W. S. and P. L. Solano 2003;Harwood, H. J., J. Fountain, and G Livermore 1998). Contributing to this problem are an estimated 119,000 heroin users, 2.3 million cocaine users, and 4.7 million Americans who used pain killers illicitly in 2003 (Substance Abuse and Mental Health Services Administration 2004). Social costs are estimated to average $\$ 22,000$ annually per illicit drug user ( $\$ 160$ billion/7.3 million users) (Cartwright, W. S. and P. L. Solano 2003). An estimated 7.3 million illicit drug users could be classified as needing specialty treatment for their drug problem (Substance Abuse and Mental Health Services Administration 2004). Of these, 1.5 million (20.8\%) were estimated to perceive a need for drug abuse treatment. However, only 1.1 million (15\%) illicit drug users actually received treatment for illicit drugs (Substance Abuse and Mental Health Services Administration 2004). Revenue from treatment came from a variety of sources, out of pocket $(40.3 \%)$, private health insurance (32.1\%), Medicaid (24.0\%), public assistance (21.1\%), Medicare (16.4\%), or with the help of family members (19\%) (Substance Abuse and Mental Health Services Administration 2004).

That only $21 \%$ of those with illicit drug problems recognized a need for treatment and only $15 \%$ actually obtained treatment is the basis of a policy dilemma. Treatment could help to reduce the external costs that illicit drug users impose on society via crime, interpersonal violence, spread of disease (e.g. HIV/AIDS and TB), and the socially insured health harms which drug users suffer. Many drug users now enter treatment through coercion from the criminal justice system. For example, In California, Proposition 36 was passed in 2000 to 
allow of those convicted of 1st and 2nd time nonviolent, simple drug possession to receive drug treatment instead of incarceration (www.prop36.org).

For illicit drug users who recognize a need for treatment, subsidies for treatment can be justified on the basis of the large social externalities caused by drug illicit drug use. Methadone maintenance treatment is estimated to cost $\$ 82$ per week and many in methadone stay in treatment for months (Roebuck, M. C., M. T. French, and A. T. McLellan 2003). However, studies have shown that treatment is cost effective (Cartwright, W.S. 2000;JofreBonet, M and JL Sindelar 2001;McCollister, K.E. and M.T. French 2003). Thus, it is in society's interest to ensure that those who desire treatment can obtain it and can receive effective, high quality care. Further, longer lengths of stay have been shown to produce greater benefits (Zarkin, G.A., L.J. Dunlap, J.W. Bray, and W.M. Wechsberg 2002). Despite the compelling public interest, it is thought that there is inadequacy of public funding to provide the good-quality, accessible care that would benefit not only the drug users but society at large. One way to expand the system would be to use price discrimination to provide revenue to clinics by encouraging individuals who are willing to pay to do so more often than currently occurs.

A rational approach to budgeting treatment subsidies would not require underwriting $100 \%$ of treatment for every client. One could use a method of Ramsey pricing to base the subsidy for various drug users on their elasticity of demand (Baumol, William J. and David F. Bradford 1970). Ramsey pricing would set up a regime of price discrimination that maximizes revenue to the drug rehabilitation system by charging more for those with higher demand and less for those with lower demand. To optimize a Ramsey pricing system in drug treatment services, information on the price elasticity and how it varies by program and 
user characteristics would be needed. However, information on price elasticity for the demand for treatment for illicit drug use is not currently available (Cartwright, W. S. and P. L. Solano 2003), but see (Borisova, N. N. and A. C. Goodman 2003) on travel time elasticity. The willingness of ordinary citizens to provide public support has been studied using contingent valuation survey methods in mall-intercept samples from Brooklyn, NY and the Triad area of North Carolina where investigators derived a mean willingness to pay of $\$ 37$ per payer towards expansion of drug treatment programs (counseling based, not methadone) to treat an additional 100-500 patients per year (Zarkin, G. A., S. C. Cates, and M. V. Bala 2000).

The objective of this paper is to inform cost-sharing strategies among users, providers and payers of drug rehabilitation. In section 1, we develop a welfare economics model of the optimal subsidy that a social planner would pay to underwrite the drug rehabilitation of an illicit drug user. Section 2 describes the primary data collected in Baltimore during 20022003 as part of a conjoint analysis to estimate the demand for drug rehabilitation and leads to section 3 where we describe the methods used to analyze the data. In section 4 we present our results. Finally in section 5 we describe limitations of the analysis and discuss implications for policy.

\section{A Model of the Optimal Subsidy}

Suppose there is a population of addicts and taxpayers. There are $\mathrm{N}^{\mathrm{A}}$ addicts who pay no taxes and $\mathrm{N}^{\mathrm{T}}$ taxpayers who pay a flat tax, $\tau$. We assume $\mathrm{N}^{\mathrm{T}}>\mathrm{N}^{\mathrm{A}}$ and define the ratio of addicts to taxpayers as: $\theta=\left(\mathrm{N}^{\mathrm{A}} / \mathrm{N}^{\mathrm{T}}\right)$. Each addict derives an identical income, $\mathrm{y}^{\mathrm{A}}$ by inflicting property losses on the taxpayers. Each taxpayer has income $\mathrm{y}^{\mathrm{T}}$ and $\mathrm{y}^{\mathrm{T}}>\mathrm{y}^{\mathrm{A}}$. The average property loss per taxpayer is $\left(\mathrm{y}^{\mathrm{A}} \mathrm{N}^{\mathrm{A}} / \mathrm{N}^{\mathrm{T}}\right)$ or $\theta \mathrm{y}^{\mathrm{A}}$. The addicts have a demand for a medical 
treatment, $m$, that is $100 \%$ successful in curing their addiction thereby converting them into taxpayers. The treatment is available at price, $p$ per episode of treatment. There is no other way to cure addiction besides purchasing the treatment. We now consider a social planner who wants to maximize social welfare by devoting all of the tax towards a Pigouvian subsidy, $s$, applied to the price of the treatment. The social planner's budget constraint is $\mathrm{N}^{\mathrm{T}} \tau=\mathrm{mN}^{\mathrm{A}} \mathrm{s}$, which implies that $\tau=\theta \mathrm{ms}$. With the simplification that each member within the two subpopulations is identical, an egalitarian social planner weighs the utility of each member of the population equally, the social planner's problem is to choose "s" in order to maximize $\mathrm{W}$ as follows:

[1] $W=N^{A} \times U^{A}\left(m_{i}, c^{A}\right)+N^{T} \times U^{T}\left(c^{T}\right)$

Normalizing the price of $c$ to be equal to 1 , the respective budget constraints can be written as:

[2] $\mathrm{y}^{\mathrm{A}}=\mathrm{c}^{\mathrm{A}}+(\mathrm{p}-\mathrm{s}) \mathrm{m}$

[3] $\mathrm{y}^{\mathrm{T}}=\mathrm{c}^{\mathrm{T}}+\tau+\theta \mathrm{y}^{\mathrm{A}}$

Inserting the budget constraints and the tax identity $\tau=\theta \mathrm{ms}$ into [1] we can recast the social welfare function as:

[4] $W=N^{A} \times\left\lfloor U^{A}\left(\left[m_{i}\right],\left[y^{A}-(p-s) m_{i}\right]\right)\right]+N^{T} \times\left\lfloor U^{T}\left(\left[y^{T}-\theta m s-\theta y^{A}\right]\right)\right\rfloor$

Define the addict's marginal rate of substitution between $\mathrm{m}$ and $\mathrm{c}$ as

$$
\psi=\frac{\frac{d U^{A}}{d m^{A}}}{\frac{d U^{A}}{d c^{A}}}
$$

Define the social rate of substitution between addict consumption and taxpayer consumption as 


$$
\varphi=\frac{\frac{d U^{T}}{d c^{T}}}{\frac{d U^{A}}{d c^{A}}}
$$

Assuming that $\mathrm{U}^{\prime}(\mathrm{c})>0$ and $\mathrm{U}^{\prime}$ '(c $)<0$, would ordinarily ensure that $\frac{d U^{T}}{d c^{T}}<\frac{d U^{A}}{d c^{A}}$

and thus that $\varphi<1$ because of the higher income and lower marginal utility of taxpayers' consumption. This would mean that redistribution of 1 unit of consumption from a taxpayer to an addict creates a utility gain for the addict that outweighs the utility loss for the taxpayer. It also is possible that addiction could also lower the marginal utility of consumption because substance use effectively satiates the pleasure centers in the brain. We simply stipulate that in general, $\frac{d U^{T}}{d c^{T}} \neq \frac{d U^{A}}{d c^{A}}$ and consider the two possibilities of $\varphi<1$ and $\varphi>1$.

The first order condition that defines the optimal subsidy s* can be written as

[5] $s^{*}=\frac{\psi}{(\varphi-1)}+\frac{p\left(1-\varphi-\varepsilon_{p}\right)}{(\varphi-1) \varepsilon_{p}}$

(See Appendix A for derivation.)

Furthermore as shown in Appendix A,

[6] $\frac{d s}{d \varepsilon}=\frac{p}{\varepsilon_{p}^{2}}$

So that the subsidy declines as the addict's demand for treatment becomes more elastic.

The optimal subsidy is 0 when

$$
\psi=\frac{p\left(\varphi-1+\varepsilon_{p}\right)}{\varepsilon_{p}}
$$


For the typical case where $\varphi<1$ and $\varepsilon_{\mathrm{p}}<1$, the point at which the optimal subsidy is zero occurs at non-negative values of $\psi$ when addicts have a high willingness to pay for their own treatment. The optimal subsidy can become negative (e.g. a surtax on treatment) if addicts have very high willingness to pay for treatment $\psi>>0$ or if it is socially optimal to redistribute wealth from addicts to taxpayers because $\varphi>>1$. The optimal subsidy is negative whenever $\psi>\frac{p\left(1-\varphi-\varepsilon_{p}\right)}{\varepsilon_{p}}$.

The foregoing considerations apply to the optimal subsidy assuming that all addicts are equal and have stable preferences. As is well-known both from field experience with addicts and from economic theory (Dockner, Engelbert and Gustav Feichtinger 1993), an individual addict's demand for treatment waxes and wanes over time. If each addict had cyclic preferences so that their demand for treatment exhibited regular peaks and troughs, the optimal subsidy would need to be tailored to each addict as their willingness to comply with treatment waxed and waned. One could, in principle, assess demand for treatment by repeatedly measuring an individual addict's demand elasticity and then calibrate incentives and subsidies to keep pace with dynamic shifts in demand. As equation [6] indicates the optimal subsidy would have to keep pace with $1 / \varepsilon^{2}$. A more feasible approach would be to find easily measured predictors of demand for drug rehabilitation services in order to follow the dynamic evolution of these markers.

\section{Study population}

Between January, 2002 and January, 2003, 247 heroin injection drug users (IDUs) who requested and were granted an available methadone maintenance treatment slot by the 
Needle Exchange Program (NEP) program staff were invited to participate in a randomized, controlled trial of strengths-based case management vs. usual methadone maintenance. The participation rate among those invited to participate was approximately $99.2 \%$ (245 of 247). Within 7 days of the initial interview, only $34 \%$ of the participants followed through and actually enrolled into the treatment slot to which they were assigned.

Details of this randomized trial are available elsewhere (Strathdee, S. A., Erin Ricketts, S Huettner, Llewellyn J. Cornelius, D Bishai, Jennifer R. Havens, P. Beilenson, C Rapp, J.J. Lloyd, and Carl A. Latkin 2006). For IDUs who agreed to enter the trial, a signed consent was obtained and a baseline interview was conducted prior to the treatment intake appointment. This study was approved by the Johns Hopkins Bloomberg School of Public Health Committee on Human Research.

To develop the survey instrument, we held key informant interviews with drug rehabilitation case managers and their administrator. These revealed that price, duration of effect and the availability of case management would be the most salient program features to inquire about. We studied five different prices $(\$ 5, \$ 25, \$ 40, \$ 60$, and $\$ 100$ per week); two different availabilities of case management (available or not); and three different durations of treatment effect $(3,6$, or 24 months of freedom from heroin). In order to cover a complete and orthogonal set of these product features with minimal respondent burden we consulted Sawtooth software (Louviere, Jordan J. 1988;Sawtooth Software Inc. 1999), and concluded that two parallel sets of 18 sequential choices among were necessary. Subjects were randomized so that half of them saw each set. Each of the 18 choices imposed a new array of three hypothetical methadone maintenance program descriptions listing the price, duration of effect, and presence of case management (See Figure 1). All subjects were told to expect 
that they would have to pay for the hypothetical program themselves because insurance would not reimburse for the treatment. Cards were-randomized so that each of the 5 prices was faced in about $20 \%$ of encounters, each case-management choice in roughly $50 \%$ and each effect duration in roughly $33 \%$ of product encounters. After viewing the three options, subjects were asked, "From these three cards, which program would you PREFER? The subsequent question was "Would you actually enroll in this program?".

Each version included one choice set in which one program clearly dominated the other two- a choice having case management, longer treatment effects, and lowest price. Subjects who preferred dominated programs were flagged.

\section{Statistical Analysis}

The evaluation of each of these 54 drug treatment programs $(18$ sets $\times 3$ programs per set) always occurred in the context of exactly 2 competitor programs. The respondents indicated both which program they preferred and, in a separate question, whether or not they would pay for the preferred program. This analysis studies the responses to the second question- "whether they would pay".

The dependent variable in our model is a binary variable indicating whether the respondent would pay out of pocket to enter treatment with the preferred set of characteristics out of each set of the three alternatives. The independent variables are the attributes (price, duration, and heroin-free time) of the programs considered and the baseline personal characteristics (e.g. socio-economic-demographic as well as addiction severity indices). The generalized linear model which we studied takes the form

$$
E(Y)=g^{-1}\left[\left(\beta{ }_{P} P_{k}+\beta{ }_{D}{ }_{D} \operatorname{Dur}_{k}+\beta{ }_{S} S_{k}+\beta{ }_{A} X\right)+\left(\mu_{\text {Question }}+\mu_{\text {Subject }}+\varepsilon\right)\right]
$$


where $\mathrm{g}^{-1}()$ is an inverse logistic link function and $\left(\mu_{\text {Question }}+\mu_{\text {Subject }}\right)$ are separate random effects associated with each of the 18 questions and each of the 245 subjects. $\mathrm{Y}$ is an indicator of whether the subject would pay for the program and $\mathrm{P}_{\mathrm{k}}$ is a vector of the program's own price and the prices of the 2 competing programs appearing within each set of the 18 card sets. Dur ${ }_{k}$ and $S_{K}$ are respectively, vectors of "own" and two competing durations of freedom from heroin and "own" and two competing indicators of availability of case management. The vector $\mathrm{X}$ represents individual respondent characteristics that might influence choice.

We first estimated this model using maximum likelihood methods based on the “gllam” program in Stata TM (Rabe-Hesketh, Sophia and Anders Skrondal 2002). We subsequently ran simple logit models without any random effects specification. The increased efficiency of the computationally intensive maximum likelihood approach led to smaller standard errors but coefficient estimates that were very close to the simple logit estimates. The significance of the coefficients was the same for the random effects and simple logit models. To ease interpretation we exponentiated the logit coefficients to obtain estimates of odds ratios. We also used the "mfx" command in Stata 8.0 to convert the coefficients into marginal effects that could be interpreted as own price and cross price elasticities. These arc elasticities have the conventional interpretation: the percentage increase in quantity demanded from a percentage decrease in price. The elasticity will only be valid around the means of all of the covariates in the sample. It will reflect the response to one program in an environment where there are 2 alternatives each with the mean price, 
duration, and case management availability of the products on the 18 sets of programs. It will also reflect the mean income and perceived risk characteristics of the sample.

\section{Results}

For this sample of heroin users, the mean daily expenditure on heroin was \$64.63 (SD $\$ 47.31$ ), excluding two outliers who reported spending over $\$ 1000$ per day on heroin. Table 1 shows the basic descriptive data from the sample. The sample had a majority of nonHispanic African Americans and males. Self-reported income had a mean of \$1207, a median $\$ 855$, and a maximum of $\$ 8000$ per month. Only $8.5 \%$ of respondents were employed. Over $38 \%$ of respondents reported deriving income from illegal sources; there may be underreporting.

Respondents were asked to express a preference for one of the three hypothetical treatment programs in each of the 18 card sets. Out of the 245 subjects, there were 5 refusals to answer preference questions leading to the collection of preference statements for $18 \times 240$ sets of three goods. After indicating which of the three was preferred, respondents were asked if they would pay the stipulated fee to enroll. The data describe the outcomes for 18 card sets $\times 3$ programs per card set $\times 240$ subjects $=12,960$ non-independent opportunities to express a willingness to purchase and or a preference.

Figures 2 and 3 visually summarize the preference data. Figure 2 shows that the subjects intended to purchase the lowest priced ( $\$ 5.00$ per week) program $63 \%$ of the time when it was coupled with the promise of 24 months free of heroin. This willingness to purchase at $\$ 5.00$ fell to $40 \%$ with only 6 months free of heroin and to $36 \%$ if only 3 months. Figure 2 provides some face validity; the proportion intending to enroll decreases systematically with: 1) price for a given time free heroin, and 2) time free from heroin at each 
price. That is, the slopes are downward sloping and increase by time heroin-free. Similarly, Figure 3 demonstrates that the presence of case management increases the probability of enrolling by about $10-20 \%$, holding the fee constant.

Figures 2 and 3 can be used to calculate a summary measure of willingness to pay using "the area under each curve" and the data on the predicted probabilities of purchase. This can be done using a logit model of equation [7] (excluding the "X" variables) to impute the probability of purchase $\quad \hat{\pi}_{\mathrm{i}}$ for the "i-th" respondent $)$, for each of the 12,960 respondent-product pairs and data on the prices and other product attributes. The area under each of the curves in Figures 2 and 3 are $\Sigma_{\mathrm{i}}\left(\hat{\pi_{\mathrm{i}}} \times\right.$ Price $\left._{\mathrm{i}}\right)$ where Price $\mathrm{i}_{\mathrm{i}}$ is the price of the " $\mathrm{i}$ -

\section{$\wedge$}

th" encountered product. One could interpret $\left(\pi_{\mathrm{i}} \times\right.$ Price $\left._{\mathrm{i}}\right)$ as the statistically expected revenue from the "i-th" person-product encounter and offer summary measures of this distribution to convey willingness to pay of the sample. The skewness of the distribution makes the median a better summary measure than the mean (Mitchell, R. and R. Carson 1989). If a drug rehabilitation program practiced perfect price discrimination in a range between $\$ 5$ and $\$ 100$, the median expected revenue per client (corresponding to area under the curve in Figure 2) would be $\$ 17.11, \$ 8.42$, and $\$ 7.39$ for programs that offered 24,6 , and 3 months of heroin-free time. For Figure 3, the corresponding summary measures are $\$ 13.05$ and $\$ 7.40$ for programs that do and do not offer case management respectively. However, these numbers could be underestimates of the true WTP as our 5 price points do not exhaust the full range of demand. As can be seen in Figure 2, there remain as many as $40 \%$ of subjects who say they would purchase treatment at $\$ 100$ per week. If these percentages 
remain high at prices of $\$ 150, \$ 200$, or even $\$ 250$, there could be substantial private willingness to pay that is unmeasured in our model.

Table 2 explores whether or not models of willingness to pay are robust to the inclusion or exclusion of the $21 \%$ of subjects who were willing to purchase dominated products. Table 3 shows that the effects of price and product attributes on WTP are nearly identical whether or not all subjects are included. Case management increases willingness to pay, whether or not irrational responders are included, which confirms our assumption that case management is generally perceived as a normal good. In separate analyses (not shown) a dummy variable indicating having preferred dominated choices had no effect on the probability of declaring a willingness to pay. We ran additional analysis (not shown) to predict the probability of making a dominated choice. The odds of preferring a dominated product were associated with several background variables, including seldom attending church (lower odds), homelessness (higher odds) and being married (lower odds) but not with schooling attainments. To maximize the power of the sample, all of the subjects were retained for subsequent models and background variables were retained as covariates.

In Table 3 we display the results of 4 different multivariate models of the willingness to pay using logistic regression. Product attributes, especially price, are the most powerful determinants of the decision to purchase and personal attributes including the preference for dominated options have a very weak interaction with the effects of price. The principal sociodemographic background variables associated with WTP were co-residence with females or with parents, which increased WTP and frequent religious service attendance which decreased WTP. A separate study of the data from this trial confirmed that living with a sexual partner increased threefold the odds of actually entering treatment (Lloyd, J. J., E. P. 
Ricketts, S. A. Strathdee, L. J. Cornelius, D. Bishai, S. Huettner, J. R. Havens, and C. Latkin 2005). It may be that the highly religious may see their religious participation as a substitute for opioid agonist therapy with methadone ${ }^{1}$. The components of the addiction severity index had opposing effects. The psychiatric subscale was associated with increased willingness to pay while the medical and drug use subscales were associated with decreased willingness to pay.

Based on model 1 of Table 3, the price elasticity of demand for drug treatment was estimated at -0.39 based on a computation of marginal effects. This elasticity was estimated at the sample mean of the product attributes implying a cash price of $\$ 48$ per week of treatment, a mean stipulated treatment outcome of 10 months of freedom from heroin, and a $49 \%$ probability that there would be case management services available.

\section{Discussion}

Our study revealed that drug addicts have a relatively inelastic demand for methadone maintenance treatment with an arc elasticity of -0.39 . This is the first estimate of price elasticity in the literature. This estimate of elasticity is contingent on the setting of this study and the set of hypothetical program parameters, as well as the characteristics of the sample population. Thus, the estimate of the price elasticity is not as generalizable as we would like. However, as the first estimate, we hope that it paves the way for future research. Revealed preference data from price experiments in drug treatment clinics are difficult to obtain. Knowledge of the price elasticity is important as there are many applications to policy issues.

\footnotetext{
${ }^{1}$ Marx may have had a different phenomenon in mind when he declared that "Religion is the opiate of the masses."
} 
There is scant literature on the sensitivity of demand to program characteristics. An important prior study (Borisova, N. N. and A. C. Goodman 2003) showed that addicts have a willingness to pay for reductions in travel time to methadone maintenance, but did not address the price elasticity of treatment.

Our results have face validity in that increments in desirable program attributes such as availability of case management and the program's stipulated time free from heroin dependence led to increments in demand. Also, we were able to provide stronger validation through revealed preference. The 245 respondents in our trial were randomized after our survey to treatment with case management (Strengths Based Case Management (SBCM)) or without case management. Assignment was revealed right after the WTP survey was conducted and subjects who were assigned to SBCM immediately received an initial session with a case manager. We subsequently observed whether the client actually followed through with the referral and later enrolled in the assigned treatment program by record linkage with the Baltimore Substance Abuse System. As reported in a separate paper 39.8\% of clients assigned SBCM enrolled in treatment, compared to $26.5 \%$ of those in the control arm (Strathdee, S. A., Erin Ricketts, S Huettner, Llewellyn J. Cornelius, D Bishai, Jennifer R. Havens, P. Beilenson, J. J. Lloyd, C Rapp, and Carl A. Latkin 2004). This 12.8 percentage point difference in enrollment rates is similar to the difference between the demand curves for case management in the two curves shown in Figure 3.

We found that product attributes, especially price, are the most powerful determinant of the decision to purchase. Thus, program characteristics may be the best vehicle on which to base price discrimination. 
Policy Implications. The key policy issue is how to increase the number of heroin users who obtain treatment. Our findings suggest a perhaps greater role for private payments. With Ramsey pricing and price discrimination for private payers, the total revenue for treatment clinics could be expanded. Currently, there is ample price discrimination not only by individuals paying out of pocket, but also by public payers and private insurers. However, taking a Ramsey pricing approach might help to optimize the system and to provide greater benefits through treatment. The administrative challenges of actually imposing a system of Ramsey prices that charged each client in perfect proportion to their willingness to pay would be formidable. Instead of individual level price discrimination, market segmentation might be more likely. The market could be segmented perhaps by clinic or by program within a clinic, with some clinics or programs offering higher service quality or specific services which would attract those more willing to pay. Our study shows that case management or concierge type services increase willingness to pay. Issues of equity might surface with such price discrimination, but this concern would by partially offset by the potential to increase funds for treatment. The cyclical nature of demand would be difficult to address, however, as addicts drop in and out of treatment repeatedly during the course of their disease. It would be far better to use a dynamic subsidy system to keep individuals in treatment, but it would be quite difficult to design an effective, dynamic subsidy system.

Although our estimates suggest a role for private payments, our estimates of expected revenue from heroin addicts fall significantly short of being able to finance the full cost of drug rehabilitation. According to our estimates, a drug rehabilitation system that could maintain a discriminatory pricing regimen would obtain a median expected revenue per addict of $\$ 7.40$ to $\$ 17.11$ per week with a clientele similar to our sample. This would not 
cover the cost of outpatient methadone maintenance programs which average $\$ 82$ per week, with the least cost program at $\$ 42$ per week (Roebuck, M. C., M. T. French, and A. T. McLellan 2003). This suggests that subsidies ranging from $\$ 65$ to $\$ 75$ per patient per week would be necessary in order to make up the difference. Note that counseling based drug treatment costs considerably less and the length of stay is much shorter, but there are no data on WTP.

One could argue for subsidies equal to the full cost of treatment because of the large negative externalities of drug use joint with the fact that drug users seems resistant to entering treatment on their own (many come to treatment under the duress of the criminal justice). Indeed, a prior study found that the availability of free drug treatment was the most important predictor of actual treatment entry (Booth, R. E., C. Kwiatkowski, M. Y. Iguchi, F. Pinto, and D. John 1998). However, co-payments generate income and the revenue could be used to increase the supply of treatment slots and conduct outreach. Demand for treatment might be increased by using the revenue for social marketing (e.g. public service announcements) if some of the revenues accrued to government payers. To the extent that providers reap some of the revenue of higher co-payments, they could finance marketing campaigns for their clinics which might spillover benefits to increasing the overall demand as well as attract clients to their specific clinic.

Another alternative to increasing demand would be to pay drug addicts to seek treatment. The optimal co-payment for selected addicts could be negative in order to attract addicts who presently have no desire for treatment. "Contingency management" techniques are currently being designed to pay those in treatment to attend counseling sessions and to make payments contingent on verified abstinence from drugs. Some of the systems are 
designed with escalating payments systems which increase the price of use of drugs over time and with 'booster payments'. These systems have been found to be effective and could perhaps serve as the basis of a dynamic negative subsidy (Petry, N.M., J. Pierce, M.L.

Stitzer, J. Blaine, J.M. Roll, and A. Cohen 2005).

This study shows that drug addicts' demand depends on price, service amenities and perceived treatment outcomes. Estimates of addicts' price elasticity for drug treatment have many policy applications, one of which is the development of an optimal subsidy system. Segmentation of the market for drug rehabilitation is currently practiced in many urban areas and enables programs to charge differential user fees based on accompanying amenities like service hours and locations. The appropriate deployment of cost-sharing mechanisms can increase the revenue for programs and potentially free up public funds to further expand treatment availability and conduct outreach. Informed and thoughtful development of costsharing mechanisms for drug treatment can expand service capacity and reduce the negative externalities associated with drug use. 


\section{References}

Baumol, William J. and David F. Bradford. 1970. "Optimal Departures from Marginal Cost Pricing." American Economic Review, 60:3, pp. 265-83.

Booth, R. E., C. Kwiatkowski, M. Y. Iguchi, F. Pinto, and D. John. 1998. "Facilitating treatment entry among out-of-treatment injection drug users." Public Health Rep, 113 Suppl 1, pp. 116-28.

Borisova, N. N. and A. C. Goodman. 2003. "Measuring the value of time for methadone maintenance clients: willingness to pay, willingness to accept, and the wage rate." Health Econ, 12:4, pp. 323-34.

Cartwright, W. S. and P. L. Solano. 2003. "The economics of public health: financing drug abuse treatment services." Health Policy, 66:3, pp. 247-60.

Cartwright, W.S. . 2000. "Cost-benefit analysis of drug treatment services: Review of the literature." Journal of Mental Health Policy Economics, 3, pp. 11-26.

Dockner, Engelbert and Gustav Feichtinger. 1993. "Cyclical Consumption Patterns and Rational Addiction." American Economic Review, 83:1, pp. 256-63.

Harwood, H. J., J. Fountain, and G Livermore. 1998. The Economic Costs of Alcohol and Drug Abuse in the United States, 1992. Bethesda, MD: NIH.

Jofre-Bonet, M and JL Sindelar. 2001. "Drug Treatment as a Crime Fighting Tool." Journal of Mental Health Policy and Economics, 4:4, pp. 175-88. 
Lloyd, J. J., E. P. Ricketts, S. A. Strathdee, L. J. Cornelius, D. Bishai, S. Huettner, J. R. Havens, and C. Latkin. 2005. "Social contextual factors associated with entry into opiate agonist treatment among injection drug users." Am J Drug Alcohol Abuse, 31:4, pp. 555-70.

Louviere, Jordan J. 1988. Analyzing Decision-Making: Metric Conjoint Analysis. London: Sage Publications.

McCollister, K.E. and M.T. French. 2003. "The relative contribution of outcome domains in the total economic benefit of addiction interventions: A review of first findings " Addiction, 98:12, pp. 1647-59.

Mitchell, R. and R. Carson. 1989. Using Surveys to Value Public Goods: The Contingent Valuation Method. Washington, DC: Resources for the Future.

Petry, N.M., J. Pierce, M.L. Stitzer, J. Blaine, J.M. Roll, and A. Cohen. 2005. "Prize-based incentives improve outcomes of stimulant abusers in outpatient psychosocial treatment programs: A national drug abuse treatment clinical trials network study." Archives of General Psychiatry, 62, pp. 1148-56.

Rabe-Hesketh, Sophia and Anders Skrondal. 2002. "Reliable estimation of generalized linear mixed models using adaptive quadrature." The Stata Journal, 2:1, pp. 1-21.

Roebuck, M. C., M. T. French, and A. T. McLellan. 2003. "DATStats: results from 85 studies using the Drug Abuse Treatment Cost Analysis Program." J Subst Abuse Treat, 25:1, pp. 51-7. 
Sawtooth Software Inc. 1999. The CBC System User's Manual. Evanston, IL: Sawtooth Technologies.

Strathdee, S. A., Erin Ricketts, S Huettner, Llewellyn J. Cornelius, D Bishai, Jennifer R. Havens, P. Beilenson, J. J. Lloyd, C Rapp, and Carl A. Latkin. 2004. "Case Management Improves Entry into Drug Treatment among Injection Drug Users Referred from a Needle Exchange Program." Johns Hopkins University: Baltimore.

Strathdee, S. A., Erin Ricketts, S Huettner, Llewellyn J. Cornelius, D Bishai, Jennifer R. Havens, P. Beilenson, C Rapp, J.J. Lloyd, and Carl A. Latkin. 2006. "Case Management to Improve Entry into Drug Treatment Among Injection Drug Users Referred from a Needle Exchange Program." In Press.

Substance Abuse and Mental Health Services Administration. 2004. Overview of Findings from the 2003 National Survey on Drug Use and Health. Rockville, MD: Office of Applied Studies.

Zarkin, G. A., S. C. Cates, and M. V. Bala. 2000. "Estimating the willingness to pay for drug abuse treatment: a pilot study." J Subst Abuse Treat, 18:2, pp. 149-59.

Zarkin, G.A., L.J. Dunlap, J.W. Bray, and W.M. Wechsberg. 2002. "The Effect of Treatment Completion and Length of Stay on Employment and Crime in Outpatient Drug-free Treatment." Journal of Substance Abuse Treatment, 23:4, pp. 261-71. 


\section{Tables}

Table 1. Sample Descriptives

\begin{tabular}{|l|r|r|l|}
\hline & $\begin{array}{l}\text { Number } \\
\text { Non } \\
\text { Missing }\end{array}$ & $\begin{array}{l}\text { Mean or } \\
\text { Frequency }\end{array}$ & $($ SD) \\
\hline Age at interview in years & 245 & 42.28 & $(8.09)$ \\
\hline Male & 245 & $69 \%$ & \\
\hline Married & 244 & $8 \%$ & \\
\hline Non-hispanic black & 244 & $77 \%$ & \\
\hline Non-hispanic white & 244 & $20 \%$ & \\
\hline Hispanic & 244 & $1 \%$ & \\
\hline Miles from their zip code to treatment referral & 233 & 5.02 & $(5.24)$ \\
\hline$\%$ non-self HH members female & 197 & $57 \%$ & \\
\hline Lives in other's house/apt & 243 & $65 \%$ & \\
\hline Any support from illegal & 245 & $38 \%$ & \\
\hline Individual Income per month & 244 & 1202.74 & $(1107.82)$ \\
\hline Lives with parents & 245 & $6 \%$ & \\
\hline Family Social Status ASI Subscale & 239 & 0.21 & $(0.21)$ \\
\hline Psychiatric Severity ASI Subscale & 237 & 0.16 & $(0.22)$ \\
\hline Legal Severity ASI Subscale & 231 & 0.31 & $(0.26)$ \\
\hline Alcohol Severity ASI Subscale & 237 & 0.11 & $(0.2)$ \\
\hline Drug Severity ASI Subscale & 236 & 0.39 & $(0.09)$ \\
\hline Employment Severity ASI Subscale & 234 & 0.83 & $(0.2)$ \\
\hline Medical Severity ASI Subscale & 237 & 0.30 & $(0.36)$ \\
\hline
\end{tabular}


Table 2. Estimates of WTP: Comparing results including and excluding subjects who (irrationally) preferred dominated choices

\begin{tabular}{|c|c|c|}
\hline \multirow{2}{*}{ Dependent Variable: WTP } & \multicolumn{2}{|c|}{$\begin{array}{c}\text { Individuals who } \\
\text { (irrationally) selected } \\
\text { dominated choices }\end{array}$} \\
\hline & Included & Excluded \\
\hline Price of the program under consideration & $\begin{array}{l}-0.002 \\
(7.22)^{\star \star \star}\end{array}$ & $\begin{array}{l}-0.003 \\
(8.22)^{\star *}\end{array}$ \\
\hline Availability of case management in the program under consideration & $\begin{array}{l}0.119 \\
(7.37)^{\star \star \star}\end{array}$ & $\begin{array}{l}0.166 \\
(8.34)^{\star *}\end{array}$ \\
\hline Time free of heroin in the program under consideration & $\begin{array}{l}0.009 \\
(8.70)^{* * *}\end{array}$ & $\begin{array}{l}0.012 \\
(10.99)^{* *}\end{array}$ \\
\hline Price of the first alternative & $\begin{array}{l}0.001 \\
(5.65)^{\star \star *}\end{array}$ & $\begin{array}{l}0.001 \\
(4.85)^{\star *}\end{array}$ \\
\hline Price of the second alternative & $\begin{array}{l}0 \\
(2.21)^{\star *}\end{array}$ & $\begin{array}{l}0 \\
-1.62 \\
\end{array}$ \\
\hline Availability of case management in the the first alternative & $\begin{array}{l}-0.043 \\
(2.64)^{* * *}\end{array}$ & $\begin{array}{l}-0.042 \\
(2.18)^{*}\end{array}$ \\
\hline Availability of case management in the the second alternative & $\begin{array}{l}-0.059 \\
(3.87)^{\star * \star}\end{array}$ & $\begin{array}{l}-0.017 \\
-0.9\end{array}$ \\
\hline Time free of heroin in the the first alternative & $\begin{array}{l}-0.001 \\
-1.36\end{array}$ & $\begin{array}{l}-0.007 \\
(5.32)^{\star *}\end{array}$ \\
\hline Time free of heroin in the the second alternative & $\begin{array}{l}-0.005 \\
(4.78)^{* \star *} \\
\end{array}$ & $\begin{array}{l}-0.007 \\
(5.53)^{* *}\end{array}$ \\
\hline Observations & 7506 & 5454 \\
\hline
\end{tabular}


Table 3 Logistic Models of WTP for Drug Rehabilitation

\begin{tabular}{|c|c|c|c|c|c|}
\hline & Model 1 & Model 2 & Model 3 & Model 4 & Model 5 \\
\hline $\begin{array}{l}\text { Price of the program under } \\
\text { consideration }\end{array}$ & $\begin{array}{l}-0.013 \\
(18.13) * * *\end{array}$ & $\begin{array}{l}-0.014 \\
(8.43)^{* \star \star}\end{array}$ & $\begin{array}{l}-0.013 \\
(7.97)^{\star \star \star}\end{array}$ & $\begin{array}{l}-0.015 \\
(8.50)^{\star * \star}\end{array}$ & $\begin{array}{l}-0.014 \\
(8.17)^{\star \star \star}\end{array}$ \\
\hline $\begin{array}{l}\text { Availability of case management in the } \\
\text { program under consideration }\end{array}$ & $\begin{array}{c}0.697 \\
(13.04) * * *\end{array}$ & $\begin{array}{l}0.676 \\
(5.90)^{\star * \star}\end{array}$ & $\begin{array}{l}0.710 \\
(7.41)^{\star * *}\end{array}$ & $\begin{array}{l}0.689 \\
(6.01)^{\star * \star}\end{array}$ & $\begin{array}{l}0.661 \\
(5.69)^{\star \star \star}\end{array}$ \\
\hline $\begin{array}{l}\text { Time free of heroin in the program } \\
\text { under consideration }\end{array}$ & $\begin{array}{c}0.048 \\
(15.03)\end{array}$ & $\begin{array}{l}0.045 \\
(11.27)^{\star \star *}\end{array}$ & $\begin{array}{l}0.048 \\
(12.81)^{\star * *}\end{array}$ & $\begin{array}{l}0.045 \\
(11.23)^{\star \star *}\end{array}$ & $\begin{array}{l}0.044 \\
(10.54)^{\star \star \star}\end{array}$ \\
\hline Price of the first alternative & $\begin{array}{l}0.005 \\
(8.27) * * *\end{array}$ & $\begin{array}{l}0.005 \\
(4.22)^{* * *}\end{array}$ & $\begin{array}{l}0.005 \\
(5.08)^{* * *}\end{array}$ & $\begin{array}{l}0.005 \\
(4.08)^{* * *}\end{array}$ & $\begin{array}{l}0.005 \\
(4.00)^{* * *}\end{array}$ \\
\hline Price of the second alternative & $\begin{array}{r}0.001 \\
(2.8)^{* * *}\end{array}$ & $\begin{array}{l}0.003 \\
(2.52)^{* *}\end{array}$ & $\begin{array}{l}0.002 \\
(1.49)\end{array}$ & $\begin{array}{l}0.003 \\
(2.61)^{* * *}\end{array}$ & $\begin{array}{l}0.003 \\
(2.56)^{* *}\end{array}$ \\
\hline $\begin{array}{l}\text { Availability of case management in the } \\
\text { the first alternative }\end{array}$ & $\begin{array}{l}-0.247 \\
-(4.87) * * *\end{array}$ & $\begin{array}{l}-0.228 \\
(3.05)^{\star * *}\end{array}$ & $\begin{array}{l}-0.246 \\
(3.19)^{\star * *}\end{array}$ & $\begin{array}{l}-0.232 \\
(3.08)^{\star * *}\end{array}$ & $\begin{array}{l}-0.238 \\
(3.14)^{\star * *}\end{array}$ \\
\hline $\begin{array}{l}\text { Availability of case management in the } \\
\text { the second alternative }\end{array}$ & $\begin{array}{l}-0.232 \\
-(4.48) * * *\end{array}$ & $\begin{array}{l}-0.279 \\
(3.20)^{\star * *}\end{array}$ & $\begin{array}{l}-0.232 \\
(2.95)^{\star * *}\end{array}$ & $\begin{array}{l}-0.280 \\
(3.22)^{\star * *}\end{array}$ & $\begin{array}{l}-0.275 \\
(3.13)^{\star * *}\end{array}$ \\
\hline $\begin{array}{l}\text { Time free of heroin in the the first } \\
\text { alternative }\end{array}$ & $\begin{array}{l}-0.021 \\
-(6.11) * * *\end{array}$ & $\begin{array}{l}-0.026 \\
(5.19)^{\star * \star}\end{array}$ & $\begin{array}{l}-0.020 \\
(4.09)^{\star * *}\end{array}$ & $\begin{array}{l}-0.026 \\
(5.20)^{\star * *}\end{array}$ & $\begin{array}{l}-0.024 \\
(4.69)^{\star \star \star}\end{array}$ \\
\hline $\begin{array}{l}\text { Time free of heroin in the the second } \\
\text { alternative }\end{array}$ & $\begin{array}{l}-0.033 \\
(9.56) * * *\end{array}$ & $\begin{array}{l}-0.039 \\
(7.43)^{\star \star \star}\end{array}$ & $\begin{array}{l}-0.032 \\
(6.70)^{\star \star \star}\end{array}$ & $\begin{array}{l}-0.039 \\
(7.64)^{\star \star \star}\end{array}$ & $\begin{array}{l}-0.037 \\
(7.13)^{\star \star \star}\end{array}$ \\
\hline Age at interview in years & & & $\begin{array}{l}-0.002 \\
-(0.58) \\
\end{array}$ & $\begin{array}{l}-0.001 \\
-(0.48) \\
\end{array}$ & $\begin{array}{l}0 \\
-0.15 \\
\end{array}$ \\
\hline Male & & & $\begin{array}{l}0.059 \\
-(1.34)\end{array}$ & $\begin{array}{l}-0.067 \\
-(1.22)\end{array}$ & $\begin{array}{l}-0.058 \\
-1.05\end{array}$ \\
\hline Married & & $\begin{array}{l}0.068 \\
-(0.96) \\
\end{array}$ & \begin{tabular}{|l|}
0.096 \\
$-(1.17)$ \\
\end{tabular} & $\begin{array}{l}0.066 \\
-(0.82) \\
\end{array}$ & \begin{tabular}{|l|l|}
0.123 \\
-1.43 \\
\end{tabular} \\
\hline Non-hispanic black & & & $\begin{array}{l}-0.156 \\
-(0.98) \\
\end{array}$ & $\begin{array}{l}0.065 \\
-(0.3) \\
\end{array}$ & $\begin{array}{l}0.03 \\
-0.14 \\
\end{array}$ \\
\hline Non-hispanic white & & & \begin{tabular}{|l|l|}
-0.213 \\
$-(1.55)$
\end{tabular} & $\begin{array}{l}0.012 \\
-(0.06)\end{array}$ & $\begin{array}{l}-0.025 \\
-0.14\end{array}$ \\
\hline Hispanic & & & $\begin{array}{l}-0.014 \\
-(0.05) \\
\end{array}$ & $\begin{array}{l}0.088 \\
-(0.28) \\
\end{array}$ & $\begin{array}{l}0.151 \\
-0.38 \\
\end{array}$ \\
\hline $\begin{array}{l}\text { Miles from their zip code to treatment } \\
\text { referral site }\end{array}$ & & $\begin{array}{l}0.002 \\
-(0.61) \\
\end{array}$ & & $\begin{array}{l}0.003 \\
-(0.65) \\
\end{array}$ & $\begin{array}{l}0.003 \\
-0.69 \\
\end{array}$ \\
\hline$\%$ non-self $\mathrm{HH}$ members female & & $\begin{array}{l}0.152 \\
(2.19)^{\star *}\end{array}$ & & $\begin{array}{l}0.174 \\
(2.66)^{\star * *}\end{array}$ & \begin{tabular}{|l}
0.177 \\
$(2.43)^{\star *}$
\end{tabular} \\
\hline Attends svc $<1 /$ month & & $\begin{array}{l}0.111 \\
-(1.32) \\
\end{array}$ & & $\begin{array}{l}0.097 \\
-(1.1) \\
\end{array}$ & $\begin{array}{l}0.117 \\
-1.31 \\
\end{array}$ \\
\hline Attends svc 2-3/month & & $\begin{array}{l}0.010 \\
-(0.17) \\
\end{array}$ & & $\begin{array}{l}0.017 \\
-(0.32) \\
\end{array}$ & $\begin{array}{l}-0.006 \\
-0.11 \\
\end{array}$ \\
\hline Attends svc weekly & & \begin{tabular}{|l|}
0.014 \\
$-(0.18)$
\end{tabular} & & \begin{tabular}{|l|}
0.007 \\
$-(0.08)$
\end{tabular} & $\begin{array}{l}0.022 \\
-0.28\end{array}$ \\
\hline Attends svc $>1 /$ wk & & $\begin{array}{l}-0.646 \\
(2.31)^{\star *}\end{array}$ & & $\begin{array}{l}-0.634 \\
(2.26)^{\star *} \\
\end{array}$ & \begin{tabular}{|l|l}
-0.578 \\
$(2.05)^{\star *}$
\end{tabular} \\
\hline Lives in other's house/apt & & $\begin{array}{l}0.043 \\
-(0.59) \\
\end{array}$ & & $\begin{array}{l}0.041 \\
-(0.56) \\
\end{array}$ & $\begin{array}{l}0.027 \\
-0.33 \\
\end{array}$ \\
\hline Any support from illegal & & $\begin{array}{l}0 \\
-(1.55) \\
\end{array}$ & & $\begin{array}{l}0 \\
-(1.29) \\
\end{array}$ & \begin{tabular}{|l|}
-0.094 \\
-1.49 \\
\end{tabular} \\
\hline Individual Income per month & & $\begin{array}{l}0 \\
-(1.27) \\
\end{array}$ & & $\begin{array}{ll} & 0 \\
-(1.55)^{2} & \\
\end{array}$ & $\begin{array}{l}0 \\
-1.57\end{array}$ \\
\hline Lives with parents & & $\begin{array}{l}0.242 \\
(1.78)^{*}\end{array}$ & & $\begin{array}{l}0.241 \\
(1.76)^{*}\end{array}$ & \begin{tabular}{|l}
0.272 \\
$(2.02)^{* *}$
\end{tabular} \\
\hline Psychiatric Severity ASI Subscale & & & & & $\begin{array}{l}0.254 \\
(1.99)^{* *}\end{array}$ \\
\hline Drug Severity ASI Subscale & & & & & $\begin{array}{l}-0.201 \\
(2.33)^{\star *}\end{array}$ \\
\hline Medical Severity ASI Subscale & & & & & $\begin{array}{l}-0.531 \\
-(1.57) \\
\end{array}$ \\
\hline Constant & $\begin{array}{c}-0.984 \\
-(44.98) * * * \\
\end{array}$ & $\begin{array}{c}-0.973 \\
(8.71)^{\star \star \star} \\
\end{array}$ & $\begin{array}{c}-0.809 \\
(4.75)^{\star \star \star}\end{array}$ & $\begin{array}{c}-0.935 \\
(3.93)^{\star \star \star} \\
\end{array}$ & $\begin{array}{l}-0.722 \\
(2.67)^{\star \star \star}\end{array}$ \\
\hline Observations & 12960 & 9936 & 12852 & 9882 & 9342 \\
\hline
\end{tabular}

Robust z-statistics in parentheses

${ }^{*}$ significant at $10 \% ;{ }^{* *}$ significant at $5 \% ;{ }^{* * *}$ significant at $1 \%$ 
Figure 1

Set 8

One of the 18 Sets of Cards for Each Subject

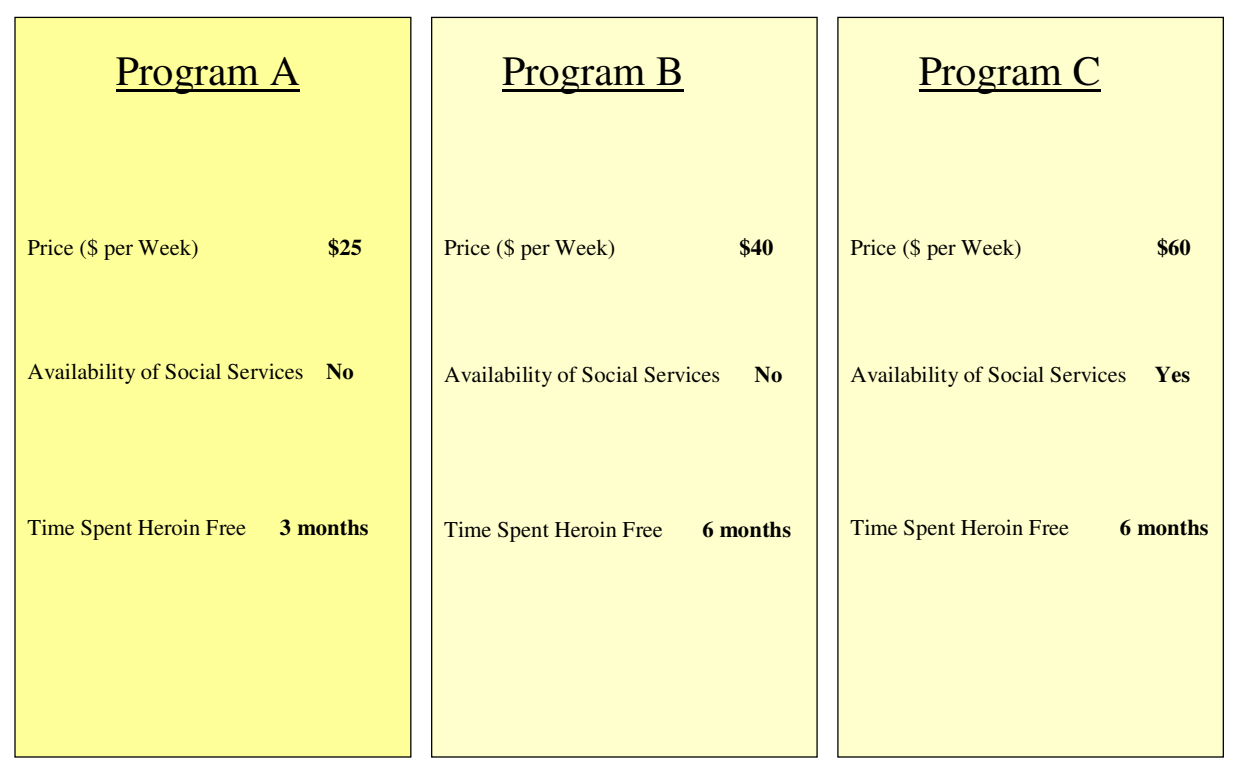

Version 1 
Figure 2

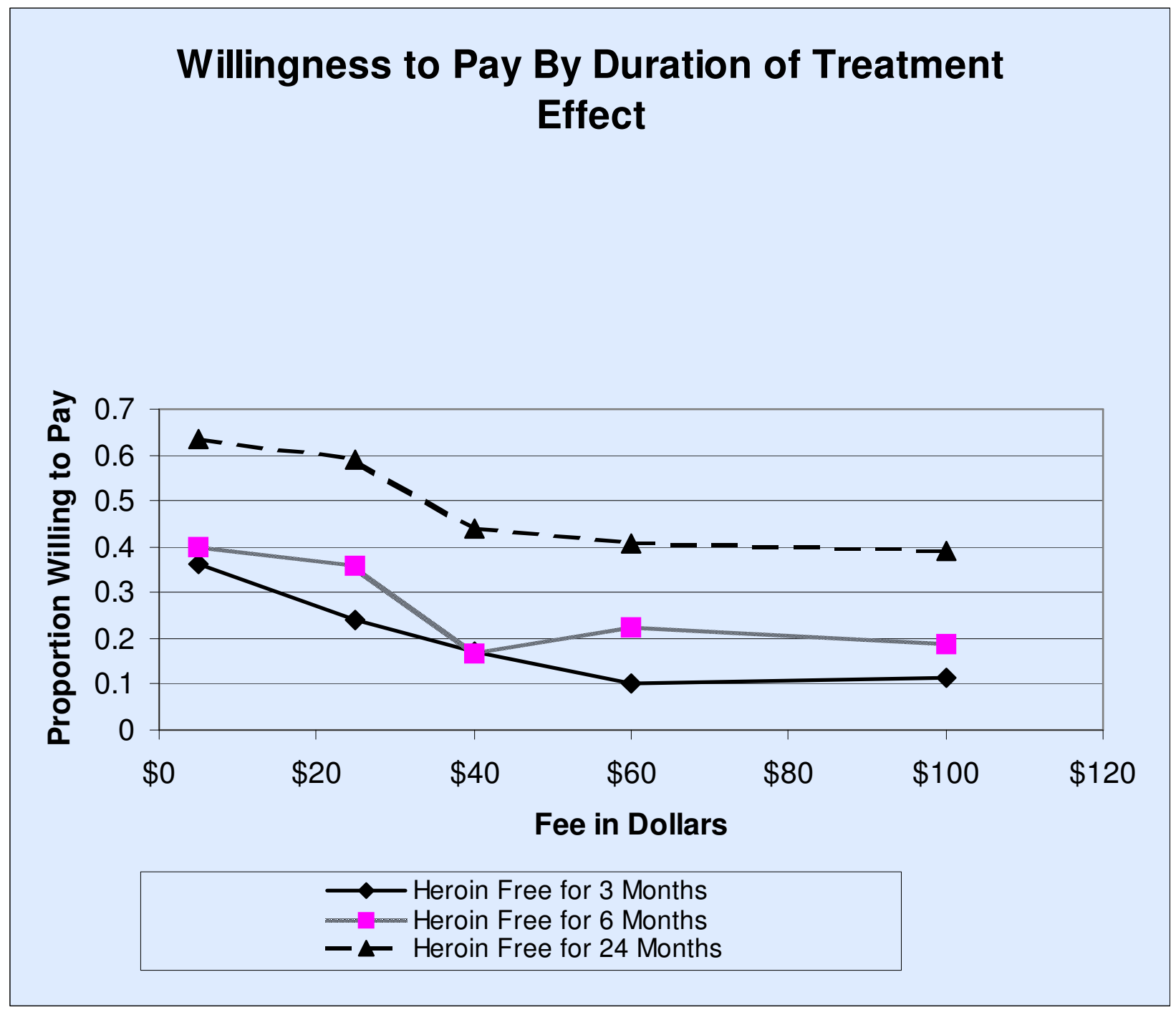




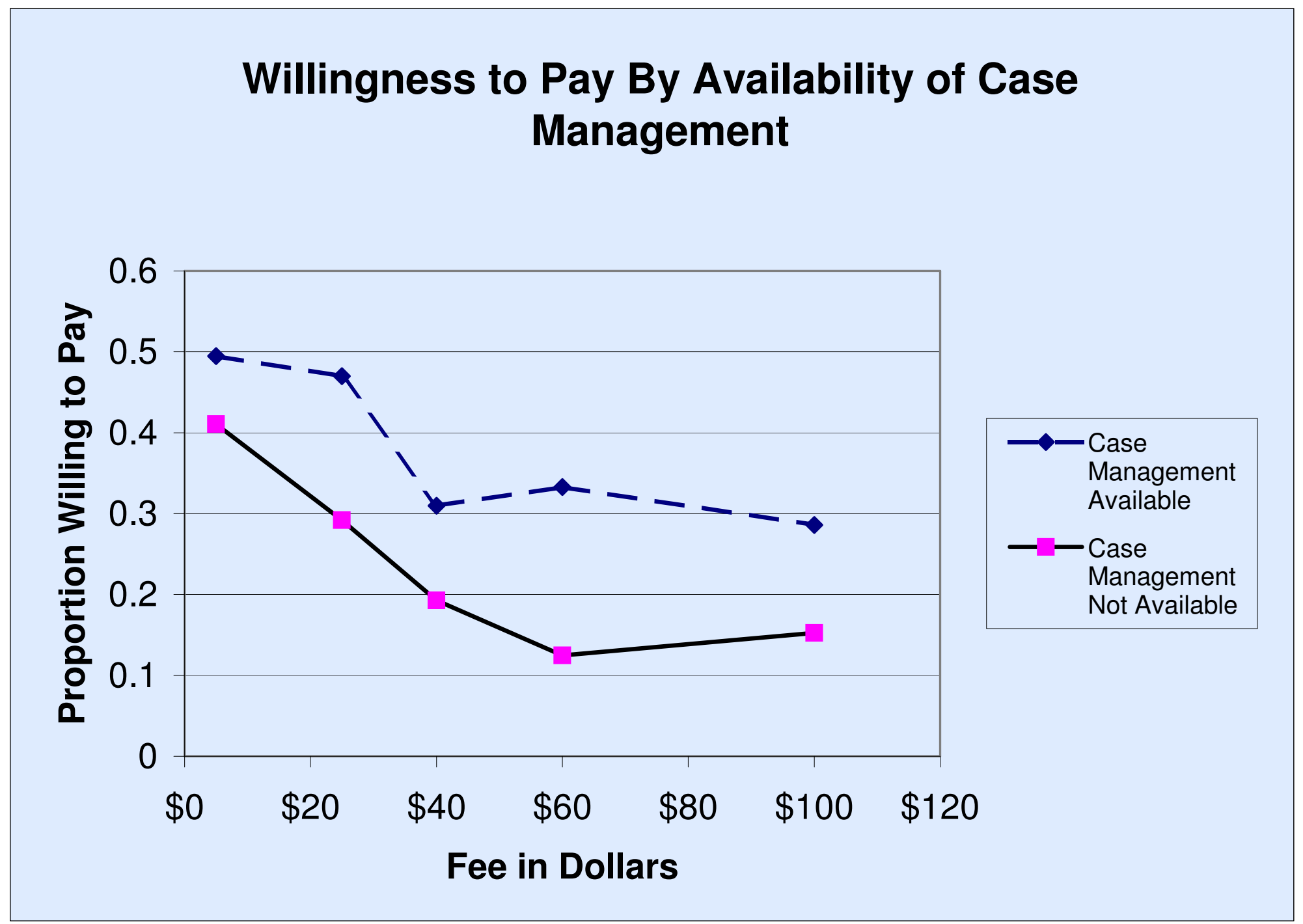




\section{Appendix A}

The first order condition for Equation 1 is:

[A1] $N^{A}\left(\frac{d U^{A}}{d m} \frac{d m}{d p}+\frac{d U^{A}}{d y}\left(m-(p-s) \frac{d m}{d p}\right)\right)+N^{T}\left(\frac{d U^{T}}{d y}\left(-\theta m-\theta s \frac{d m}{d p}\right)\right)=0$

[A2] $N^{A}\left(\frac{d U^{A}}{d m} \frac{d m}{d p}\right)=N^{A}\left(\frac{d U^{A}}{d y}\left(-m+(p-s) \frac{d m}{d p}\right)\right)+N^{T}\left(\frac{d U^{T}}{d y}\left(\theta m+\theta s \frac{d m}{d p}\right)\right)$

[A3] $N^{A}\left(\frac{d U^{A}}{d m} \frac{1}{m} \frac{d m}{d p}\right)=N^{A}\left(\frac{d U^{A}}{d y}\left(-1+\frac{(p-s)}{m} \frac{d m}{d p}\right)\right)+\theta N^{T}\left(\frac{d U^{T}}{d y}\left(1+\frac{s}{m} \frac{d m}{d p}\right)\right)$

but

$\theta N^{T}=N^{A}$ So

[A4] $\left(\frac{d U^{A}}{d m} \frac{1}{m} \frac{d m}{d p}\right)=\left(\frac{d U^{A}}{d y}\left(-1+\frac{(p-s)}{m} \frac{d m}{d p}\right)\right)+\left(\frac{d U^{T}}{d y}\left(1+\frac{s}{m} \frac{d m}{d p}\right)\right)$

noting that

$\varepsilon_{p}=\frac{d m}{d p} \frac{p}{m}$

[A5] $\frac{d U^{A}}{d m} \frac{\varepsilon_{p}}{p}=\frac{d U^{A}}{d y}\left(\left(\frac{p-s}{p}\right) \varepsilon_{p}-1\right)+\frac{d U^{T}}{d y}\left(\left(\frac{s}{p}\right) \varepsilon_{p}+1\right)$

Define

$$
\varphi=\frac{\frac{d U^{T}}{d y}}{\frac{d U^{A}}{d y}}
$$


[A6] $\operatorname{MRS}^{A}\left(\frac{\varepsilon_{p}}{p}\right)=\left(\left(\frac{p-s}{p}\right) \varepsilon_{p}-1\right)+\varphi\left(\left(\frac{s}{p}\right) \varepsilon_{p}+1\right)$

[A7] $M R S^{A} \varepsilon_{p}=p \varepsilon_{p}-s \varepsilon_{p}-p+\varphi s \varepsilon_{p}+\varphi p$

[A8] $M R S^{A} \varepsilon_{p}+p\left(1-\varphi-\varepsilon_{p}\right)=s \varepsilon_{p}(\varphi-1)$

[A9] $s=\frac{M R S^{A} \varepsilon_{p}+p\left(1-\varphi-\varepsilon_{p}\right)}{\varepsilon_{p}(\varphi-1)}$

[A10] $s=\frac{M R S^{A}}{(\varphi-1)}+\frac{p\left(1-\varphi-\varepsilon_{p}\right)}{(\varphi-1) \varepsilon_{p}}$

Applying quotient rule $\mathrm{d}(\mathrm{u} / \mathrm{v})=(\mathrm{vdu}-\mathrm{udv}) / \mathrm{v}^{2}$

$v=(\varphi-1) \varepsilon_{p}$

$d v=(\varphi-1)$

$u=p\left(1-\varphi-\varepsilon_{p}\right)$

$d u=-p$

[A11] $\frac{d s}{d \varepsilon}=\frac{\left[\left(-p \varepsilon_{p}\right)-p\left(1-\varphi-\varepsilon_{p}\right)\right]}{(\varphi-1) \varepsilon_{p}^{2}}$

[A12] $\frac{d s}{d \varepsilon}=\frac{p}{\varepsilon_{p}{ }^{2}}$ 


\section{Appendix B}

Derivation of condition for zero subsidy:

[B1] $\frac{-\psi \varepsilon_{p}}{(\varphi-1) \varepsilon_{p}}>\frac{p\left(1-\varphi-\varepsilon_{p}\right)}{(\varphi-1) \varepsilon_{p}}$

If $\varphi>1$

$[B 2]-\psi \varepsilon_{p}>p\left(1-\varphi-\varepsilon_{p}\right)$

[B3] $\psi \varepsilon_{p}<p\left(1-\varphi-\varepsilon_{p}\right)$

[B4] $\psi>\frac{p\left(1-\varphi-\varepsilon_{p}\right)}{\varepsilon_{p}}$ 


\section{Acknowledgements:}

Funding for this research was provided by grant number R01- DA09225 funded by the National Institute on Drug Abuse. In addition, the authors would like to thank study participants and staff of the Baltimore Needle Exchange Project. The authors gratefully acknowledge research support for JS from the National Institute on Drug Abuse to Yale (Grant No. R01-DA14471). 